\title{
Perancangan Alat Pendeteksi Kualitas Minyak Goreng Dengan Parameter Viskositas Dan Densitas Mengggunakan Metode Fuzzy Logic
}

\author{
Azam Zyaputra $^{1}$, Alex Surapati ${ }^{1 *}$, Reza Satria Rinaldi ${ }^{1}$ \\ ${ }^{1}$ Program Studi Teknik Elektro Fakultas Teknik Universitas Bengkulu, *alexsurapati@gmail.com
}

\begin{abstract}
AbSTRAK
The quality of cooking oil sold in the market needs to be checked to ensure its health. cooking oil quality detector is designed to make it easier for the public to know the quality of the cooking oil. The research method is to make tools and conduct testing. The test is carried out by measuring the viscosity and density using the tool made. When the viscosity of 985 fuzzification was "good", and the density was $\mathbf{5 4 2 . 9 3}$ $\mathrm{Kg} / \mathrm{mL}$ of "good" fuzzification, the fuzzification was processed by a fuzzy inference system, then defuzzification occurred in the form of oil quality results. fried "good". When the viscosity of 932 fuzzification is "sufficient", and the density is $\mathbf{6 1 8 . 6 9}$ $\mathrm{Kg} / \mathrm{mL}$ of "moderate" fuzzification, a fuzzy inference system occurs, a defuzzification process is "moderate", when the viscosity of $\mathbf{9 2 6}$ fuzzification is "bad", and a density of $631.31 \mathrm{Kg} / \mathrm{mL}$ fuzzification "bad", fuzzy inference system occurs, defuzzification process occurs with "bad" results. To ensure that the results are accurate, the sample is taken to the BPOM which measures free fatty acids. From the BPOM test results converted to viscosity and density. In order to obtain an accurate conversion value between viscosity and density, it is recommended that a large number of samples be tested..
\end{abstract}

Keywords: viscosity, density, fuzzy logic

\section{Pendahuluan}

Indonesia merupakan negara agraris yang didominasi oleh sektor pertanian sebagai andalan mata pencaharian. Perkebunan Indonesia memiliki komoditas unggulan yaitu kelapa sawit. Salah satu hasil olahan dari kelapa sawit adalah minyak goreng atau yang disebut dengan Crude Palm Oil (CPO)[1]. Produksi minyak goreng kelapa sawit di Indonesia sendiri pada tahun 2010 mencapai sebesar 3.588 ton, tahun 2011 sebesar 3.907 ton, tahun 2012 sebesar 5.272 ton, tahun 2013 sebesar 4.973 ton dan tahun 2014 sebesar 9.044 ton. Jadi rata-rata pertumbuhan setiap tahun (\%) dari 2010 sampai 2014 sebesar 31,04\% dan untuk pertumbuhan dari 2013 sampai 2014 sebesar 81,86\%. Masyarakat Indonesia mengkonsumsi minyak goreng pada tahun 2009 sebanyak 8,19 liter/kapita/tahun, di tahun 2010 sebanyak 8,03 liter/kapita/tahun, tahun 2011 sebanyak 8,24 liter/kapita/tahun, tahun 2012 sebanyak 9,33 liter/kapita/tahun, dan pada tahun 2013 sebanyak 8,92 liter/kapita/tahun. Terjadinya pertumbuhan konsumsi tersebut dari 2009 sampai 2013 rata-rata adalah sebesar $2,38 \%$ [2].

Semakin meningkatnya permintaan dari konsumen terhadap minyak goreng dari tahun ke tahun menyebabkan harga minyak goreng menjadi mahal, membuat sering terjadinya kecurangan para pedagang kuliner gorengan dengan cara menggunakan minyak goreng berulang kali untuk menggoreng [3]. Minyak goreng digunakan secara berulang maka menyebabkan oksidasi asam lemak tidak jenuh yang menyebabkan rusaknya organ tubuh seperti hati apabila organ hati rusak makan akan sangat berbahaya bagi kesehatan tubuh [4].

Kendala yang sering terjadi di masyarakat adalah masih digunakannya minyak goreng yang tidak layak lagi. Pemeriksaan terhadap kualitas minyak goreng masih dilakukan oleh masyarakat secara manual. Di era sekarang terdapat banyak teknologi yang menggunakan Artificial Intelligence untuk memudahkan manusia dalam menentukan pengambilan keputusan, salah satu Artificial Intelligence yang sering digunakan adalah metode fuzzy logic [5].

Permasalahan penelitian ini adalah bagaimana merancang alat pendeteksi kualitas minyak goreng dengan parameter viskositas dan densitas menggunakan fuzzy logic dan korelasi antara hasil fuzzifikasi dan hasil pengujian oleh BPOM. Tujuan penelitian ini merancang alat pendeteksi kualitas minyak goreng menggunakan fuzzy logic dan untuk menganalisis suatu karakteristik korelasi keluaran antara sensor LDR dan loadcell terhadap parameter kualitas minyak goreng serta menganalisis tingkat akurasi dan presisi alat pendeteksi minyak goreng. 


\section{KERANGKA TEORITIS}

Minyak goreng merupakan salah satu bahan pokok sehari-hari yang dipakai oleh masyarakat Indonesia. Minyak goreng memiliki berbagai macam jenis seperti minyak goreng kelapa sawit, minyak goreng dari kacang dan yang lainnya. Penggunaan minyak goreng secara berulang akan merusak kualitas minyak goreng hal ini dikarenakan meningkatnya asam lemak bebas dari minyak goreng, terjadinya peningkatan asam lemak bebas pada minyak goreng akan memicu perubahan viskositas, densitas, dan yang lainnya pada minyak goreng [6].

Viskositas adalah tingkat kekentalan dari suatu fluida yang menyebabkan terjadinya gesekan internal ketika terjadi pergerakan benda pada fluida tersebut[7]. Ada beberapa cara yang dapat digunakan untuk melakukan proses pengukuran viskositas fluida seperti metode kromatografi, metode spektrofotometer, metode viskometer, metode ostwald, metode bola jatuh, bahkan sudah ada metode pengukuran viskositas secara otomatis dengan memanfaatkan LED dan LDR menggunakan deteksi sensor cahaya [8], [9].

Densitas merupakan jumlah atau kuantitas suatu zat pada suatu unit volume [10]. Densitas yang akan digunakan sebagai parameter pada penelitian ini adalah massa jenis. Secara manual, densitas massa jenis dapat diukur dengan membandingkan massa dan volume benda tersebut menggunakan Persamaan 1.

$$
\rho=\frac{m}{V}
$$

dengan:

$$
\begin{array}{ll}
\rho & =\text { Densitas }\left(\mathrm{Kg} / \mathrm{m}^{3}\right) \\
\mathrm{m} & =\text { Massa benda }(\mathrm{Kg}) \\
\mathrm{V} & =\text { Volume benda }\left(\mathrm{m}^{3}\right)
\end{array}
$$

Pengukuran massa jenis secara otomatis dapat dilakukan dengan menggunakan sensor berat berupa load cell [11] yang dapat dimanfaatkan untuk mengukur massa jenis dengan menggunakan konsep pada Persamaan 1

Kecerdasan buatan merupakan manipulasi simbolsimbol untuk menyelesaikan suatu masalah menurut pendapat dari Bruchanan dan Shortliffe. Staugarad dan Marvin Minsky juga mengemukakan suatu pendapat mengenai pengertian kecerdasan buatan, yaitu suatu ilmu pengetahuan yang dapat membuat mesin melakukan sesuatu yang memerlukan kecerdasan apabila dikerjakan oleh manusia. Dengan demikian, kecerdasan buatan merupakan suatu bidang ilmu sains komputer yang berfungsi untuk menyempurnakan kerja suatu sistem instrumentasi elektronika. Peralatan yang dibangun dapat melakukan kerja yang memerlukan kecerdasan seperti yang dimiliki manusia [12].
Salah satu algoritma yang dikatakan dalam kecerdasan buatan komputasional adalah Logika Fuzzy. Secara bahasa, logika Fuzzy diartikan sebagai logika kabur atau samar antara benar atau salah, dimana bisa diartikan juga dalam teori suatu nilai tersebut dapat berupa benar atau salah secara bersamaan. Tapi berapa besar nilai kebenaran dan kesalahan tergantung pada nilai keanggotaan yang dimiliki [13].

Sistem inferensi fuzzy adalah sistem penarikan kesimpulan dari logika fuzzy dengan menggunakan beberapa kaidah, FIS merupakan masukan nilai eksak juga rules dalam hukum logika fuzzy. Cara kerja logika fuzzy dapat dilihat pada Gambar 1 yang merupakan struktur elemen dasar sistem inferensi fuzzy:

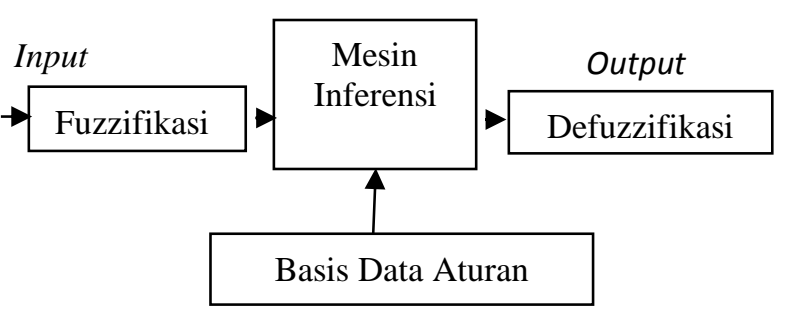

Gambar 1 Struktur Fuzzy Inference System [14].

Cara kerja logika fuzzy inferensi sistem meliputi tahapan: 1. Fuzzifikasi

Fuzzifikasi adalah proses niali masukan sistem berupa nilai tegas menjadi variable linguistik menggunakan suatu fungsi keanggotaan lalu disimpan kedalam basis pengetahuan.

2. Pembentukan basis pengetahuan pada logika fuzzy (Rule dalam bentuk IF...THEN)

3. Mesin Inferensi.

Proses untuk mengubah masukan fuzzy menjadi keluaran fuzzy dengan mengikuti aturan (IFTHEN Rules) yang telah dibuat dan ditetapkan pada pengetahuan fuzzy. 4. Agregasi.

Agregasi adalah dimana terjadinya masalah aturan terdiri lebih dari satu. Artinya hasil suatu Implikasi mempunyai nilai lebih dari satu. Sering terjadinya maslah tersebut akhirnya diperlukan mengkombinasikan semua nilai hasil tersebut menjadi satu fuzzy set yang tunggal. Metode agregasi yang digunakan di sini adalah metode $\min$

5. Defuzzifikasi

Defuzzifikasi adalah proses untuk mengubah keluaran fuzzy yang diterima dari mesin inferensi menjadi nilai tegas memakai fungsi keanggotaan yang sama dengan saat dilakukan proses dari Fuzzifikasi [14]. 
Fungsi keanggotaan (membership function) adalah suatu kurva yang memperlihatkan pemetaan titik-titik masukan data kedalam nilai keanggotaannya atau biasa disebut kadar keanggotaan yang memiliki selisih 0 sampai 1. Untuk mendapatkan nilai keanggotaan salah satu caranya adalah melalui pendekatan fungsi [15].

\section{METOde RISET}

Penelitian dimulai dengan merancang dan membuat alat pendeteksi kualitas minyak goreng, kemudian dilakukan berbagai pengujian sistem. Pengujian terhadap kualitas minyak goreng dilakukan dengan menggunakan metode pendekatan untuk mengetahui korelasi antara viskositas dan densitas minyak goreng terhadap kualitas minyak goreng berdasarkan asam lemak bebas minyak goreng. Sampel minyak goreng terlebih dahulu akan diukur viskositas dan densitasnya dengan alat yang sudah jadi, kemudian sampel minyak goreng akan dibawa ke BPOM setempat untuk diukur kualitas minyak goreng berdasarkan asam lemak bebas. Pada penelitian ini akan menggunakan 3 sampel dengan viskositas dan densitas yang berbeda untuk dibawa ke BPOM.

Diagram blok sistem berfungsi untuk menunjukkan hubungan antar komponen perancangan yang menggambarkan sistem secara keseluruhan. Diagram blok secara umum dari perancangan alat pendeteksi kualitas minyak goreng dapat dilihat pada Gambar 2.

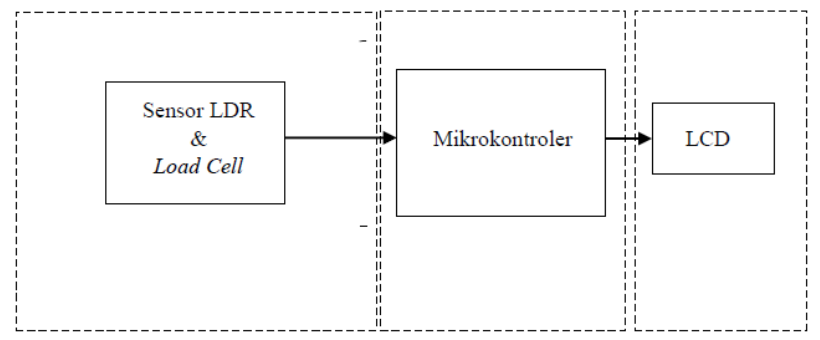

Gambar 2 Diagram Blok Sistem Perancangan

Gambar 2 menunjukkan bahwa sistem pendeteksi kualitas minyak goreng tersebut dirancang menjadi sistem open loop yang terdiri dari dua macam sensor, yaitu sensor LDR dan load cell. Ketika cahaya dari laser diarahkan pada minyak goreng maka minyak goreng yang memiliki viskositas tertentu akan menghambat gerak cahaya, sehingga sebagian cahaya akan membias dan sebagian lagi diteruskan ke LDR. Cahaya yang diteruskan tersebut kemudian akan mengenai LDR untuk dibaca bit ADCnya. Bit ADC yang terbaca oleh sensor LDR inilah yang akan menjadi parameter acuan dari viskositas sampel. Pengukuran berat sampel minyak goreng dilakukan dengan menggunakan load cell. Mikrokontroler setelah itu akan mendeteksi tingkat kualitas minyak goreng yang akan ditampilkan pada LCD.
Perancangan alat pendeteksi kualitas minyak goreng dibuat dalam dua tahapan perancangan, yaitu perancangan perangkat keras dan perancangan perangkat lunak. Perancangan perangkat keras bertujuan untuk merangkai seluruh komponen alat pendeteksi kualitas minyak goreng hingga terbentuk rancangan. Perancangan perangkat lunak bertujuan sebagai sistem kendalinya pada mikrokontroler yang akan mengolah data kualitas minyak goreng.

Urutan dalam merancang tahap demi tahap perintah yang akan diberikan biasanya diperjelas dengan menggunakan bagan alir yang biasa disebut dengan flowchart. Flowchart atau diagram alir berfungsi untuk menggambarkan urutan proses kerja dari suatu sistem. Pada penelitian ini dapat dilihat proses sistem kerjanya pada Gambar 3

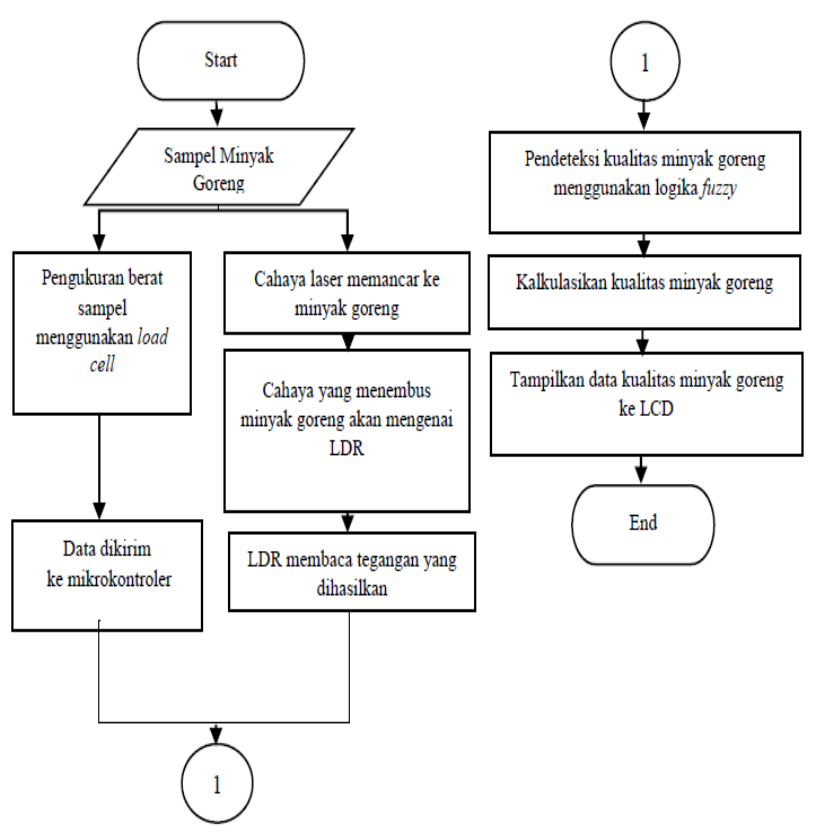

Gambar 3 Flowchart Penelitian

\section{Hasil Dan Pembahasan}

Proses pengujian secara keseluruhan terbagi menjadi tiga tahapan, yaitu pengujian dasar masing-masing komponen, pengujian korelasi masing-masing sensor terhadap kualitas minyak goreng, dan pengujian sistem secara keseluruhan. Sebelum memulai tahap pengujian lebih lanjut, setiap komponen harus terlebih dahulu dipastikan dalam kondisi baik agar setiap data yang dihasilkan lebih akurat, sehingga dilakukanlah pengujian masing-masing komponen seperti Arduino, power supply, LCD, sensor LDR dan sensor load cell. Setelah semua komponen dipastikan dalam keadaan baik, maka dilakukanlah pengujian utama pada penelitian ini. 


\subsection{Pengujian Sensor LDR}

Pengujian sensor yang pertama dilakukan pada sensor LDR (Light Dependent Resistor). Pengujian sensor LDR dilakukan dengan mengamati nilai keluaran bit ADC yang terbaca oleh sensor saat mengukur kualitas minyak goreng dengan variasi pemakaian yan berbeda. Adapun data hasil pengujian karakteristik sensor LDR dapat dilihat pada Tabel 1.

TABEL 1

Data Hasil Pengujian Sensitifitas Sensor LDR

\begin{tabular}{|c|c|c|c|c|c|c|c|c|c|c|c|c|c|}
\hline \multirow{2}{*}{ No } & \multirow{2}{*}{$\begin{array}{c}\text { Sampel } \\
\text { Minyak } \\
\text { goreng }\end{array}$} & \multicolumn{12}{|c|}{ Bit ADC Keluaran Sensor LDR pada Detik Ke- } \\
\hline & & 0 & 1 & 2 & 3 & 4 & 5 & 6 & 7 & 8 & 9 & 10 & $\begin{array}{l}\text { Rata- } \\
\text { Rata }\end{array}$ \\
\hline 1 & Sampel 1 & 990 & 989 & 990 & 990 & 989 & 988 & 990 & 991 & 990 & 989 & 980 & 988.73 \\
\hline 2 & Sampel 2 & 985 & 985 & 986 & 986 & 985 & 986 & 986 & 986 & 986 & 986 & 985 & 985.6 \\
\hline 3 & Sampel 3 & 985 & 985 & 986 & 985 & 986 & 986 & 985 & 985 & 985 & 986 & 985 & 985.36 \\
\hline 4 & Sampel 4 & 940 & 940 & 940 & 939 & 939 & 940 & 940 & 939 & 940 & 940 & 939 & 939.6 \\
\hline 5 & Sampel 5 & 932 & 932 & 930 & 930 & 932 & 930 & 929 & 930 & 929 & 931 & 931 & 930.5 \\
\hline 6 & Sampel 6 & 923 & 921 & 923 & 923 & 922 & 921 & 923 & 921 & 923 & 923 & 923 & 922.36 \\
\hline 7 & Sampel 7 & 917 & 915 & 916 & 915 & 917 & 915 & 915 & 917 & 917 & 916 & 916 & 916 \\
\hline 8 & Sampel 8 & 904 & 906 & 905 & 905 & 905 & 904 & 905 & 906 & 906 & 906 & 906 & 905.27 \\
\hline 9 & Sampel 9 & 855 & 854 & 856 & 856 & 855 & 855 & 853 & 856 & 856 & 853 & 855 & 854.91 \\
\hline 10 & $\begin{array}{c}\text { Sampel } \\
10\end{array}$ & 815 & 816 & 816 & 816 & 816 & 815 & 816 & 815 & 816 & 816 & 816 & 815.73 \\
\hline
\end{tabular}

Data hasil pengujian pada Tabel 1 menunjukkan bahwa sensor LDR memiliki sensitivitas yang cukup baik jika digunakan untuk mendeteksi kualitas minyak goreng. Pada pengujian sensor perbedaan pembacaan sensor LDR untuk kualitas minyak goreng sampel 1 dan sampel 10 memiliki selisih rata-rata 73 bit. Selain itu nilai pembacaan rata-rata keluaran sensor LDR selama 10 detik tersebut tidak terlalu linier. Pada sampel 1 hingga 10 bit keluaran ADC terus turun sehingga didapatkan suatu nilai yang linier.

Selain karakteristik sensor berupa sensitivitas, Tabel 1 menunjukkan bahwa sensor load cell memiliki respon waktu yang cukup baik saat pengukuran tingkat kualitas minyak goreng. Pada detik pertama sensor LDR sudah memiliki respon yang menunjukkan nilai ADC dari cahaya yang dilewatkan ke sampel minyak goreng. Begitu pula dengan respon waktu saat mengukur dengan menggunakan sampel minyak goreng yang berbeda. Berdasarkan Tabel 1 dapat pula dilihat karakteristik linieritas dari sensor LDR. Untuk memperjelas karakteristik linieritas dari sensor LDR, data hasil pengujian pada Tabel 1 akan diubah menjadi bentuk grafik seperti pada Gambar 4

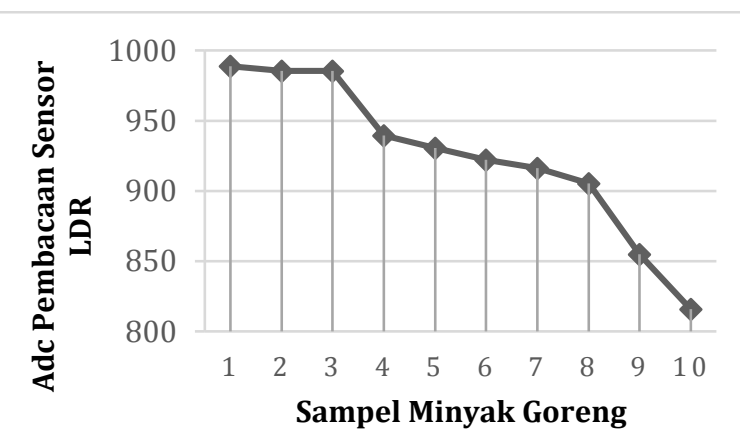

Gambar 4. Grafik Pengujian Linieritas Sensor LDR

Berdasarkan Gambar 4 data hasil pembacaan sensor LDR sudah cukup linier terhadap parameter tingkat kualitas minyak goreng. Pada percobaan pertama ADC yang terbaca saat sampel 1 minyak goreng adalah 988,73. Kemudian nilai ADC terus menurun saat sampel minyak goreng yang dipakai berbeda, sehingga saat sampel 10 nilai ADC yang terbaca adalah sebesar 815,73. Linieritas sensor LDR pada pengujian sensor LDR cukup bagus.

\subsection{Pengujian Karakteristik Sensor Load Cell}

Pengujian sensor yang kedua adalah sensor load cell yang digunakan untuk mengukur massa jenis (densitas) dari minyak goreng. Pada pengujian kali ini suhu yang digunakan $25^{\circ} \mathrm{C}$. Proses pengukuran densitas minyak goreng dilakukan dengan mengukur massa minyak goreng menggunakan load cell pada volume yang tetap kemudian nilai pembacaan load cell akan dibagi dengan volumenya menggunakan Persamaan 1. Pada penelitian ini volume yang digunakan dibuat konstan yaitu 79,2 mL, untuk mempermudah proses pengukuran massa jenisnya. Proses pengukuran dilakukan menggunakan minyak goreng dengan sampel variasi tingkat pemakaian yang berbeda-beda. Adapun data hasil pengujian sensitivitas sensor berat terhadap kualitas minyak goreng dapat dilihat pada Tabel 2 .

TABEL 2

Data Hasil Pengujian Sensitifitas Dan Respon WAKTU SENSOR LOAD CELL

\begin{tabular}{ccccccccccccccc}
\hline & & \multicolumn{1}{c}{ Bampel } & \multicolumn{1}{c}{ Berat Minyak Goreng Hasil Pengukuran Load Cell (Gram) } \\
\cline { 3 - 14 } No & $\begin{array}{c}\text { Minyak } \\
\text { goreng }\end{array}$ & 0 & 1 & 2 & 3 & 4 & 5 & 6 & 7 & 8 & 9 & 10 & $\begin{array}{c}\text { Rata- } \\
\text { rata }\end{array}$ \\
\hline 1 & Sampel 1 & 0 & 41 & 41 & 41 & 41 & 41 & 41 & 41 & 42 & 42 & 41 & 37,45 \\
\hline 2 & Sampel 2 & 0 & 43 & 42 & 42 & 42 & 42 & 42 & 42 & 42 & 42 & 43 & 38,36 \\
\hline 3 & Sampel 3 & 0 & 46 & 46 & 46 & 45 & 46 & 46 & 45 & 45 & 45 & 45 & 41,36 \\
\hline 4 & Sampel 4 & 0 & 46 & 46 & 46 & 46 & 46 & 46 & 45 & 45 & 46 & 45 & 41,55 \\
\hline 5 & Sampel 5 & 0 & 49 & 48 & 49 & 48 & 49 & 49 & 48 & 49 & 49 & 49 & 44,27 \\
\hline 6 & Sampel 6 & 0 & 49 & 49 & 49 & 49 & 49 & 48 & 49 & 49 & 48 & 49 & 44,36 \\
\hline 7 & Sampel 7 & 0 & 49 & 49 & 49 & 50 & 50 & 50 & 49 & 50 & 50 & 50 & 45,09 \\
\hline 8 & Sampel 8 & 0 & 50 & 50 & 49 & 51 & 51 & 50 & 51 & 50 & 50 & 50 & 45,64 \\
\hline 9 & Sampel 9 & 0 & 51 & 50 & 51 & 51 & 51 & 52 & 51 & 51 & 52 & 51 & 46,45 \\
\hline 10 & Sampel 10 & 0 & 52 & 52 & 52 & 52 & 53 & 52 & 53 & 52 & 52 & 53 & 47,55 \\
\hline & & & & & & & & & & & & &
\end{tabular}


Berdasarkan Tabel 2 data hasil pengukuran berat dari load cell setiap variasi sampel minyak goreng berbeda-beda semakin banyak minyak goreng dipakai maka densitasnya semakin tinggi. Hal tersebut menunjukkan bahwa ada hubungan antara kualitas minyak goreng dan densitas minyak goreng serta sensitivitas sensor load cell cukup bagus untuk mengukur kualitas minyak goreng. Data hasil pembacaan sensor tersebut menunjukkan bahwa antara sampel minyak goreng 1 dan sampel minyak goreng 10 memiliki selisih berat 10,1 gram saat volumenya 79,2 mL.

Selain karakteristik sensor berupa sensitivitas, Tabel 2 menunjukkan bahwa sensor load cell memiliki respon waktu yang cukup baik saat pengukuran kualitas minyak goreng. Pada detik kedua sensor load cell sudah memiliki respon yang menunjukkan nilai berat minyak goreng yang terbaca. Begitu pula dengan respon waktu saat mengukur dengan menggunakan sampel minyak goreng yang berbeda. Berdasarkan Tabel 2 dapat pula dilihat karakteristik linieritas dari sensor load cell. Untuk memperjelas karakteristik linieritas dari sensor load cell, data hasil pengujian pada Tabel 2 akan diubah menjadi suatu bentuk grafik seperti pada Gambar 5 .

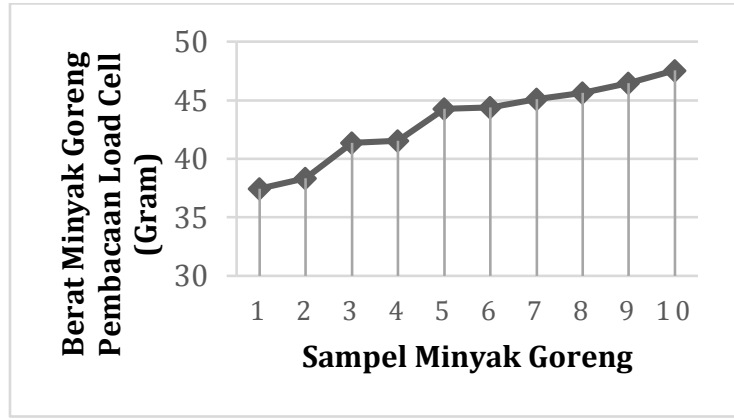

Gambar 5. Grafik Pengujian Linieritas Sensor Load Cell

Berdasarkan Gambar 5 data hasil pembacaan sensor load cell sudah cukup linier terhadap parameter kualitas minyak goreng. Pada percobaan pertama berat rata-rata yang terbaca saat sampel 1 adalah 37,45 gram. Kemudian beratnya terus meningkat hingga saat sampel 10 berat rata-ratanya adalah sebesar 47,55 gram. Pengujian linieritas sensor load cell cukup bagus.

\subsection{Penggunaan Metode Fuzzy}

Logika fuzzy yang dibuat menghasilkan beberapa himpunan keanggotaan berdasarkan parameter viskositas dan densitas minyak goreng sesuai sistem perancangan. Logika fuzzy kemudian akan dikombinasikan ke program arduino untuk menjadi sistem keseluruhan agar perancangan sistem dapat berjalan.

\subsubsection{Fuzzifikasi}

Pada proses fuzzifikasi, variabel viskositas dan densitas dibagi menjadi beberapa fungsi keanggotaan tertentu. Variabel viskositas terbagi menjadi 3 himpunan fuzzy yaitu "buruk", "cukup" dan "baik" (seperti pada Gambar 6) dan tiga himpunan fuzzy untuk variabel densitas yaitu "bagus", "sedang",dan "jelek" (seperti pada Gambar 7 ).

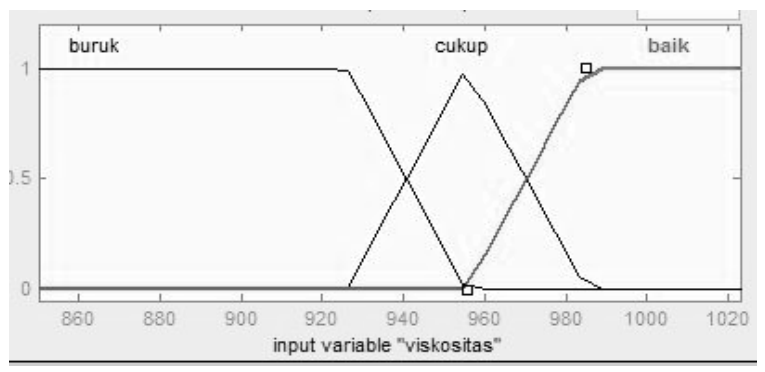

Gambar 6. Himpunan Fuzzifikasi Viskositas Minyak Goreng

Pada himpunan untuk parameter viskositas akan dilakukan dengan mengukur nilai ADC dari sensor LDR, variabel himpunan viskositas akan dibagi menjadi 3 , masing-masing variabel nilai akan dibuat dengan mengacu pada data hasil uji kualitas minyak goreng di BPOM. Hasil pengujian menyatakan ketika viskositas 985 memenuhi syarat untuk digunakan yang berati masih baik, dan viskositas 926 tidak memenuhi syarat yang berati sudah buruk, dengan mempertimbangkan jarak hasil baik dan buruk tersebut maka diambillah titik tengah antara kedua jarak tersebut sebagai viskositas cukup yaitu 956. Setelah itu dibuatlah fuzzifikasi viskositas dengan ketentuan sebagai berikut,

$1.0 \mathrm{~s} / \mathrm{d} 956$ masuk dalam himpunan "buruk"

2. $926 \mathrm{~s} / \mathrm{d} 985$ masuk dalam himpunan "cukup"

3. $956 \mathrm{~s} / \mathrm{d} 1023$ masuk dalam himpunan "baik"

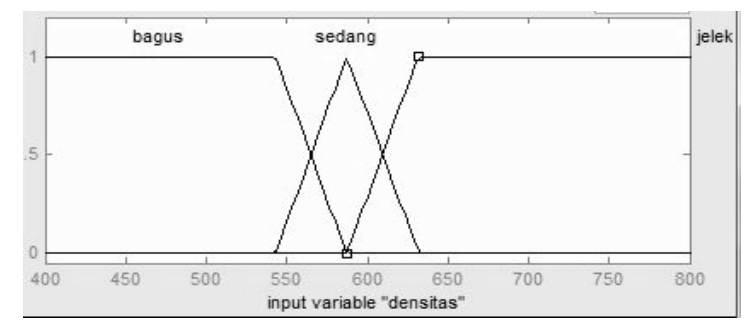

Gambar 7. Himpunan Fuzzifikasi Densitas Minyak Goreng

Pada himpunan untuk parameter densitas minyak goreng akan dilakukan dengan mengukur nilai densitas masing-masing sampel minyak goreng, variabel himpunan akan dibagi menjadi 3 dan masing-masing variabel nilai akan dibuat dengan mengacu pada data hasil uji kualitas minyak goreng di BPOM. Hasil pengujian menyatakan ketika densitas $542,93 \mathrm{Kg} / \mathrm{mL}$ memenuhi syarat untuk digunakan yang berati masih bagus, dan densitas $631,31 \mathrm{Kg} / \mathrm{mL}$ tidak memenuhi syarat yang berati sudah jelek, dengan mempertimbangkan jarak hasil baik dan buruk tersebut maka diambillah titik tengah antara kedua jarak tersebut sebagai densitas sedang yaitu 
$587 \mathrm{Kg} / \mathrm{mL}$. Setelah itu dibuatlah fuzzifikasi densitas dengan ketentuan sebagai berikut:

1. $400(\mathrm{Kg} / \mathrm{mL}) \mathrm{s} / \mathrm{d} 587(\mathrm{Kg} / \mathrm{mL})$ masuk dalam himpunan "bagus"

2. $542,93(\mathrm{Kg} / \mathrm{mL})$ s/d $631,3(\mathrm{Kg} / \mathrm{mL})$ masuk dalam himpunan "sedang"

3. $587(\mathrm{Kg} / \mathrm{mL}) \mathrm{s} / \mathrm{d} 800(\mathrm{Kg} / \mathrm{mL})$ masuk dalam himpunan "jelek"

\subsubsection{Inferensi Fuzzy}

Setelah proses fuzzifikasi selesai maka dilakukan proses inferensi fuzzy dengan mengkombinasikan masingmasing himpunan, pada proses sistem inferensi fuzzy akan dilakukan dengan menggunakan metode mamdani dengan mengkombinasikan masing-masing himpunan pada tiap parameter. Setelah itu akan disusun sebanyak 9 aturan (rule) sebagai berikut:

1. If Viskositas is Buruk and Densitas is Jelek then Output is Kualitas Buruk. (aturan 1).

2. If Viskositas is Buruk and Densitas is Sedang then Output is Kualitas Buruk. (aturan2).

3. If Viskositas is Buruk and Densitas is Bagus then Output is Kualitas Buruk. (aturan3).

4. If Viskositas is Cukup and Densitas is Jelek then Output is Kualitas Buruk. (aturan 4).

5. If Viskositas is Cukup and Densitas is Sedang then Output is Kualitas Sedang. (aturan 5).

6. If Viskositas is Cukup and Densitas is Bagus then Output is Kualitas Sedang. (aturan 6).

7. If Viskositas is Baik and Densitas is Jelek then Output is Kualitas Buruk. (aturan 7).

8. If Viskositas is Baik and Densitas is Sedang then Output is Kualitas Sedang. (aturan 8).

9. If Viskositas is Baik and Densitas is Bagus then Output is Kualitas Baik. (aturan 9).

Berdasarkan aturan fuzzy (rules) yang telah disesuaikan dengan kondisi yang dibutuhkan, maka dapat disajikan hasilnya pada Tabel 3 .

TABEL 3

RUELS INFERENSI FUZZY

\begin{tabular}{lllll}
\hline No & Viskositas & & Sedang & Bagus \\
\hline 1 & Buruk & Kualitas Buruk & Kualitas Buruk & Kualitas Buruk \\
\hline 2 & Cukup & Kualitas Buruk & Kualitas Sedang & Kualitas Sedang \\
\hline 3 & Baik & Kualitas Buruk & Kualitas Sedang & Kualitas Baik \\
\hline
\end{tabular}

Setelah dilakukan proses inferensi fuzzy dari kombinasi ketiga inputan maka didapat 9 aturan (rules). Berikut output yang dihasilkan dari pembacaan aturan fuzzy (fuzzy rules) seperti pada Gambar 8.

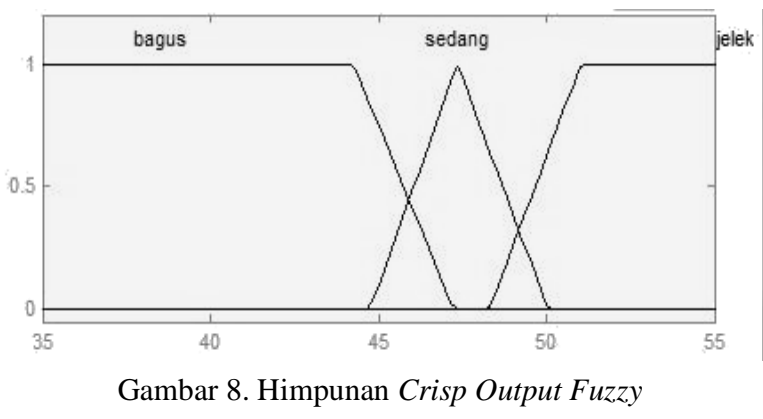

Untuk Himpunan Crisp Output Fuzzy yang dibuat terdapat tiga himpunan yaitu, "Grade C", "Grade B”,dan“"Grade A”. Himpunan tersebut digunakan sebagai dasar untuk mengambil keputusan.

\subsection{Hasil Pengujian Alat Keseluruhan Menggunakan Metode Fuzzy Logic}

Pengujian ini dilakukan bertujuan untuk melihat hasil kinerja sistem alat melakukan proses fuzzy yang sudah diunggah ke dalam mikrokontroler Arduino Uno. Hasil pengujian fuzzy logic dapat dilihat pada Tabel 4.

TABEL 4

Hasil Pengujian Fuzzy LogiC

\begin{tabular}{|c|c|c|c|c|c|c|}
\hline \multirow{2}{*}{$\begin{array}{l}\text { Sampel } \\
\text { Minyak } \\
\text { Goreng }\end{array}$} & \multirow{2}{*}{$\begin{array}{l}\text { Viskositas } \\
\text { Minyak } \\
\text { Goreng } \\
\text { (ADC) }\end{array}$} & \multirow{2}{*}{$\begin{array}{c}\text { Densitas } \\
\text { Minyak } \\
\text { Goreng } \\
(\mathrm{Kg} / \mathrm{mL}) \\
\end{array}$} & \multirow{2}{*}{$\begin{array}{c}\text { Kualitas } \\
\text { Minyak }\end{array}$} & \multicolumn{3}{|c|}{ Tampilan LCD } \\
\hline & & & & Viskositas & Densitas & Kualitas \\
\hline Sampel 1 & 990 & 517,68 & Baik & Baik & Bagus & 45.00 \\
\hline $\begin{array}{l}\text { Sampel } 2 \\
\end{array}$ & 985 & 542,93 & Baik & Baik & Bagus & 45.00 \\
\hline Sampel 3 & 985 & 580,81 & Baik & Baik & Bagus & 45.00 \\
\hline Sampel 4 & 940 & 580,81 & Sedang & Cukup & Bagus & 45.90 \\
\hline Sampel 5 & 932 & 618,69 & Sedang & Cukup & Sedang & 45.50 \\
\hline Sampel 6 & 923 & 618,69 & Buruk & Buruk & Sedang & 49.49 \\
\hline Sampel 7 & 917 & 618,69 & Buruk & Buruk & Sedang & 49.49 \\
\hline Sampel 8 & 904 & 631,31 & Buruk & Buruk & $\begin{array}{l}\text { Jelek } \\
\end{array}$ & 55.00 \\
\hline Sampel 9 & 855 & 643,94 & Buruk & Buruk & $\begin{array}{l}\text { Jelek } \\
\end{array}$ & 55.00 \\
\hline $\begin{array}{l}\text { Sampel } 10 \\
\end{array}$ & 815 & 656,67 & Buruk & Buruk & Jelek & 55.00 \\
\hline
\end{tabular}

Dari Tabel 4 maka dapat dilihat hasil pengujian sistem kerja alat pendeteksi kualitas minyak goreng dengan menggunakan metode fuzzy logic sudah berjalan sesuai dengan rancangan program. Hasil yang diperoleh sesuai dengan aturan yang dibuat dimana ketika viskositas 990 maka akan "baik" dan densitas 517,68 maka akan "bagus", setelah itu LCD akan menampilkan kualitas minyak dengan nilai 45.00 yang dimana nilai tersebut adalah "baik", saat viskositas 932 maka akan "cukup" dan densitas 618,69 maka akan "sedang", setelah itu LCD akan menampilkan kualitas minyak dengan nilai yaitu 45.50 yang dimana nilai tersebut adalah "sedang", dan ketika viskositas 904 maka akan "buruk" dan densitas 631,31 maka akan "jelek", setelah itu LCD akan menampilkan kualitas minyak dengan nilai 55.00 yang dimana nilai tersebut adalah "buruk". 
Dari pengujian yang dilakukan, maka data yang diperoleh akan dibuat dalam bentuk grafik yang dapat dilihat pada Gambar 10.

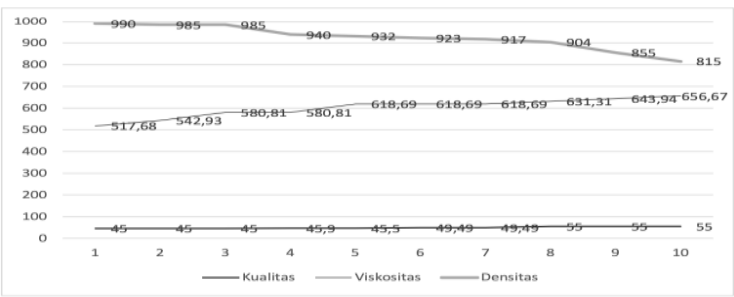

Gambar 10. Grafik Hasil Pengujian Alat

Berdasarkan Gambar 10 hasil pengujian alat maka dapat dilihat hubungan diantara viskositas, densitas dan kualitas dari suatu minyak goreng, hubungan antara viskositas dan kualitas berbanding terbalik semakin rendah viskositas minyak goreng maka hasil nilai kualitas akan semakin tinggi yang dimana berarti semakin buruk kualitas minyak goreng tersebut, ketika viskositas 990 maka nilai kualitas 45 sedangkan ketika viskositas 815 maka nilai kualitas 55, sedangkan untuk densitas berbanding lurus dengan kualitas semakin tinggi densitas minyak goreng maka semakin juga nilai kualitas yang dikeluarkan yang dimana berarti semakin buruk kualitas minyak goreng tersebut, ketika densitas 517,68 maka nilai kualitas 45 sedangkan ketika nilai densitas 656,67 maka nilai kualitas akan 55 .

\section{Penutup}

Perancangan alat pendeteksi kualitas minyak goreng berdasarkan viskositas dan densitas menggunakan metode fuzzy logic tipe mamdani. Alat menggunakan sensor LDR untuk mengukur viskositas berdasarkan bit ADC yang terukur pada sensor LDR dan load cell untuk mengukur densitas. Rata-rata pembacaan sensor LDR hanya berbeda $0 \mathrm{~s} / \mathrm{d} 5$ bit setiap waktunya yang paling besar selisih 10 bit. Rata-rata pembacaan sensor load cell berbeda $0 \mathrm{~s} / \mathrm{d} 4$ gram setiap waktunya dengan eror presisi rata-rata 1,07\% dan paling besar $2,13 \%$.

Pada penelitian ini minyak goreng yang digunakan hanya satu jenis minyak goreng disarankan peneliti selanjutnya memperbanyak varian percobaan untuk menghasilkan alat pengukur pendeteksi kualitas minyak goreng yang lebih baik lagi. Untuk meningkatkan kualitas sistem cerdas pada alat ini peneliti selanjutnya disarankan untuk mencoba mengganti metode fuzzy logic dengan metode jaringan syaraf tiruan.

\section{REFERENSI}

V. Nurmalita and P. A. Wibowo, "Analisis Faktor-
Faktor Yang Mempengaruhi Ekspor Minyak Kelapa Sawit Indonesia ke India," Econ. Educ. Anal. J., vol. 8, no. 2, pp. 605-619, 2019, [Online]. Available: https://journal.unnes.ac.id/sju/index.php/eeaj/article/vi ew/31492.

[2] M. Goi, Y. K. Yasin, and Z. I. Mohamad, "Identifikasi Penggunaan Minyak Goreng oleh Pedagang Pisang Goreng di Kecamatan Kota Tengah Kota Gorontalo," Heal. Nutr. J., vol. 3, no. 1, pp. 28-34, 2017.

[3] B. Nainggolan, N. Susanti, and A. Juniar, "Uji Kelayakan Minyak Goreng Curah dan Kemasan yang Digunakan Menggoreng Secara Berulang," J. Pendidik. Kim., vol. 8, no. 1, pp. 45-57, 2016.

[4] I. Mustikasari, F. Saktini, and A. R. Gumay, "Pengaruh Frekuensi Penggorengan Minyak Jelantah Terhadap Diameter Dan Gambaran Histopatologi Lumen Aorta Tikus Wistar (Rattus Novergicus)," Diponegoro Med. J. (Jurnal Kedokt. Diponegoro), vol. 8, no. 1, pp. 2637, 2019.

[5] H. Nasution, "Implementasi Logika Fuzzy pada Sistem Kecerdasan Buatan,” 2012.

[6] H. Herlina, E. Astryaningsih, W. S. Windrati, and N. Nurhayati, "TINGKAT KERUSAKAN MINYAK KELAPA SELAMA PENGGORENGAN VAKUM BERULANG PADA PEMBUATAN RIPE BANANA CHIPS (RBC)," J. AGROTEKNOLOGI, 2018, doi: 10.19184/j-agt.v11i02.6527.

[7] P. T. Sarjana, Perancangan alat pengukur tingkat kemurnian bensin premium menggunakan metode backpropagation. 2017.

[8] S. . Kale, A. Prasad, G. Milind, G. Prakash, and K. Nishant, "Petrochemical Quality Measurement And Adulteration Detection Using Arm Controller," Int. J. Adv. Res. Electron. Commun. Eng., vol. 4, no. 1, pp. 90-93, 2015, [Online]. Available: http://ijarece.org/wp-

content/uploads/2015/01/IJARECE-VOL-4-ISSUE-190-93.pdf.

[9] R. A. Sirait, "Penerapan Metode Spektrofotometri Ultraviolet pada Penetapan Kadar Nifedipin dalam Sediaan Tablet," Fak. Farm. Univ. Sumatra Utara, Medan., 2009.

[10] I. GUTAMA PUTRA, "Perancangan Dan Penerapan Neraca Digital Untuk Percobaanmenentukan Massa Jenis Zat Padat," Inov. Fis. Indones., vol. 3, no. 03, 2014.

[11] D. Apriani, Gusnedi, and Y. Darvina, "Studi Tentang Nilai Viskositas Madu Hutan dari Beberapa Daerah di Sumatera Barat Untuk Mengetahui Kualitas Madu," Pillar Phys., vol. 2, pp. 91-98, 2013.

[12] I. M. Mataram, Dasar Komputasi Cerdas. Artificial Neural Network. Denpasar: Universitas Udayana, 2016.

[13] S. Komariyah, R. M. Yunus, and S. F. Rodiansyah, "Logika Fuzzy Dalam Sistem Pengambilan Keputusan Penerimaan Beasiswa," Proceeding Stima 2.0, pp. 6168, 2016, [Online]. Available: http://jurnal.unma.ac.id/index.php/ST/article/view/225

[14] N. Syafitri N, “SIMULASI SISTEM UNTUK PENGONTROLAN LAMPU DAN AIR CONDITIONER DENGAN MENGGUNAKAN LOGIKA FUZZY," J. Inform., vol. 10, no. 1, pp. 11641172, 2016, doi: 10.26555/jifo.v10i1.a3348.

[15] W. Buana, "Penerapan Fuzzy Mamdani Untuk Sistem Pendukung Keputusan Pemilihan Telepon Seluler," J. Edik Inform., vol. 2, pp. 138-143, 2014. 